\title{
OPTIMALISASI LAKU PANDAI BERBASIS MASJID GUNA LITERASI DAN INKLUSI KEUANGAN SYARIAH BERKELANJUTAN
}

\author{
Syah Amelia Manggala Putri \\ Dosen Program Studi Muamalat Fakultas Agama Islam \\ Universitas Muhammadiyah Yogyakarta \\ Email: manggalaputri89@gmail.com \\ Eka Jati Rahayu Firmansyah \\ Account Officer PT. Bank BRISyariah \\ Kantor Cabang Yogyakarta Yos Sudarso \\ Email: ekajati30@gamail.com
}

ARTICLE HISTORY

Received:

6 November 2017

Accepted:

20 December

2017

Online available:

25 February 2018

Keywords:

Laku Pandai,

literacy,

inclusion,

shari'a finance, mosque

\section{ABSTRACT}

Recent development of Shari'a banking is quite satisfying. In 2016, shari'a banking has reported the asset as much as 365.6 trillion rupiahs. On the other hands, the index of shari'a financial literacy and inclusion has not been optimum that is only $8.11 \%$ and $11.06 \%$ respectively. Therefore, a new innovation is needed to increase the index of literacy and inclusion as a challenge in shari'a banking in Indonesia. As a response, Indonesia Financial Services Authority (OJK) has launched a new regulation of NonOffice Financial Services in the Framework of Inclusive Finance (Laku Pandai) which is expected to increase the index of shari'a financial inclusion. In the application, shari'a finance, which is based on the Islamic laws, should get itself closer to the centre of Islamic spiritual development, namely mosques. A mosque, however, does not only function as a place for developing spirituality but also plays an important role in improving economic activities. Hence, this study is conducted by qualitative research applying the method of Grounded Theory. The synergy between the Laku Pandai program and mosques is performed by involving ummah - the community - as the agent of Laku Pandai whose duty is to assist the community in getting suitable shari'a products and services. In this case, the products of Laku Pandai can be used in worshipping activities (qurban, umroh, hajj, etc), phone-credit recharging, and micro-shari'a financing. The application of this synergy, however, will make the products and services of shari'a finance accessible to the community and thus increase the index of shari'a financial inclusion at once. The mosque-based education about shari'a finance is obtained by Islamic studies, lectures, and socialization initiated by involved parties, religious leaders and the society, so that it will also increase the index of shari'a financial literacy. 
Kata Kunci: Laku Pandai

Literasi

Inklusi

Keuangan Syariah

Masjid

\section{ABSTRAK}

Perkembangan Perbankan syariah sangat menggembirakan. Tahun 2016 perbankan syariah mencatatkan Aset sebesar Rp. 365,6 triliun. Namun disisi lain indeks literasi dan inklusi perbankan syariah belum optimal, masing-masing sebesar $8.11 \%$ dan $11.06 \%$. Untuk menjawab tantangan tersebut dibutuhkan terobosan guna peningkatan literasi dan inklusi keuangan syariah di Indonesia. Otoritas Jasa Keuangan sudah meluncurkan regulasi mengenai Layanan Keuangan Tanpa Kantor Dalam Rangka Keuangan Inklusif (Laku Pandai) yang diharapkan bisa menaikan tingkat inklusi keuangan syariah. Keuangan syariah dalam aplikasinya bermuara kepada ajaran Islam seharusnya lebih mendekatkan diri kepada pusat spiritual keislaman yaitu Masjid. Selain berfungsi sebagai lembaga pengembangan kegiatan spiritual, Masjid mempunyai peran strategis dalam pengembangan kegiatan ekonomi. Penelitian ini merupakan penelitian kualitatif menggunakan metode grounded theory. Sinergi Laku Pandai dengan Masjid dilakukan dengan pelibatan jamaah Masjid menjadi agen Laku Pandai yang melayani masyarakat untuk mendapatkan layanan keuangan syariah. Produk Laku Pandai bisa digunakan untuk kepentingan ibadah (Qurban, Umroh, Haji dll), pembelian pulsa dan pembiayaan mikro syariah. Dengan adanya sinergi, maka masyarakat mendapatkan akses terhadap keuangan syariah sehingga akan meningkatkan inklusi keuangan syariah. Pendidikan tentang keuangan syariahpun akan didapatkan melalui kajian, ceramah dan sosialisasi dari berbagai pihak dibantu oleh tokoh agama dan masyarakat dengan berbasis Masjid sehingga akan meningkatkan indeks literasi keuangan syariah.

\section{PENDAHULUAN}

Perkembangan keuangan syariah di Indonesia cukup membanggakan. Sudah banyak kemajuan dan pencapaian positif dari aspek kelembagaan dan infrastruktur penunjang, perangkat regulasi, sistem pengawasan, awareness dan literasi masyarakat terhadap layanannya (Alanshori, 2016). Banyak negaranegara lain yang belajar untuk mengembangkan keuangan syariah dari Indonesia. Indonesia merupakan negara dengan total aset keuangan syariah terbesar ke 9 di dunia (OJK, 2017). Komposisi asset keuangan syariah di Indonesia terdiri dari perbankan syariah, reksa dana syariah, sukuk negara \& sukuk korporasi serta lembaga keuangan non bank syariah lainnya. Rincian pertumbuhan asset tersebut adalah sebagai berikut : 


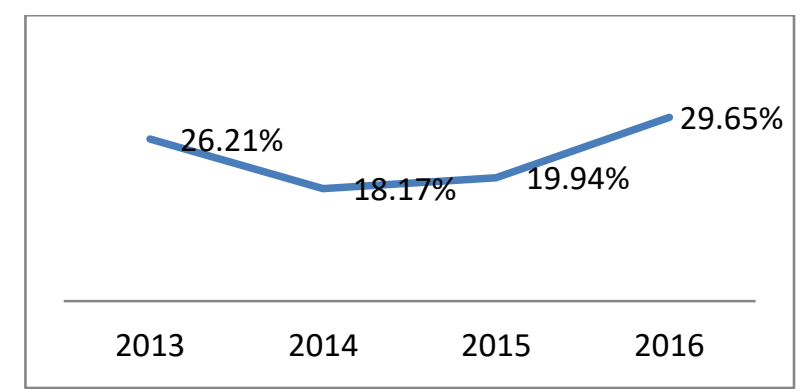

Sumber: Otoritas Jasa Keuangan, Roadmap Perkembangan Keuangan Syariah Indoneisa 2017 - 2019.

Gambar 1 : Pertumbuhan Keuangan Syariah Indonesia

Perbankan syariah yang merupakan bagian keuangan syariah di Indonesia menjadi primadona masyarakat. Menurut undang-undang nomor 21 tahun 2008 Bank syariah adalah bank yang menjalankan kegiatan usahanya berdasarkan prinsip syariah dan menurut jenisnya terdiri atas Bank Umum Syariah dan Bank Pembiayaan Rakyat Syariah. Perbankan Syariah dalam melakukan kegiatan usahanya berdasarkan Prinsip Syariah, demokrasi ekonomi, dan prinsip kehatihatian. Perbankan syariah bertujuan menunjang pelaksanaan pembangunan nasional dalam rangka meningkatkan keadilan, kebersamaan dan pemerataan kesejahteraan rakyat.

Pada akhir tahun 2016, perbankan syariah Indonesia yang terdiri dari Bank Umum Syariah (BUS), Unit Usaha Syariah (UUS) dan Bank Pembiayaan Rakyat Syariah (BPRS) mencatatkan pertumbuhan aset, pembiayaan yang diberikan (PYD) dan dana pihak ketiga (DPK) industri perbankan syariah nasional tahun 2016 tumbuh signifikan, masing-masing sebesar 20,28\%, 16,41\% dan $20,84 \%$. Total aset, pembiayaan yang diberikan (PYD), dan dana pihak ketiga (DPK) industri perbankan syariah nasional pada tahun 2016 masing-masing mencapai Rp365,6 triliun, Rp254,7 triliun dan Rp285,2 triliun (OJK, 2017). Struktur cash and saving accounts (CASA) masih menjadi tantangan dalam perbankan syariah. Pada tahun 2014 komposisi CASA perbakan syariah baru mencapai 39.6 \%. Masih mendominasinya sumber dana mahal menjadikan perbankan syariah kurang efisien dalam menjalankan usahanya. Dibandingkan dengan bank konvensional struktur CASA perbankan syariah dapat dilihat sebagai berikut : 
Putri \& Firmansyah |Jurnal Ekonomi dan Bisnis Islam, Vol. 3, No. 2, Juli-Des 2017

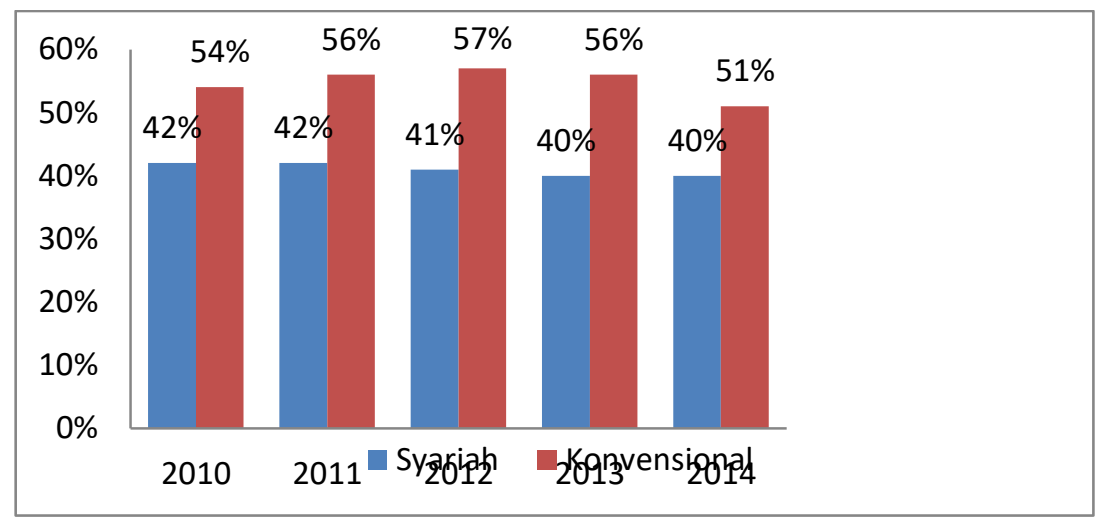

Sumber: Otoritas Jasa Keuangan, Roadmap perbankan Syariah Indoneisa 2015 2019.

Gambar 2 : Komposisi Cash and Saving Accounts (CASA)

Otoritas Jasa Keuangan (OJK) (OJK, 217) telah memaparkan peluang dan tantangan perbankan syariah di Indonesia adalah : (1). Kondisi global. (2). Standar dan komitmen internasional. (3). Integrasi sektor keuangan. (4). Pertumbuhan berkelanjutan. (5). Pemerataan pembangunan. (6). Stabilitas keuangan. (7). Bonus demografi. (8). Financing gap, potensi dan pendalaman pasar. (9). Literasi masyarakat terhadap jasa keuangan syariah masih rendah. selain peluang dan tantangan tersebut terdapat beberapa isu strategis dalam pengembangan perbankan syariah diantaranya biaya dana yang mahal serta pemahaman dan kesadaran masyarakat yang masih rendah.

Berdasarkan Survei Nasional Literasi dan Inklusi Keuangan tahun 2016, indeks inklusi keuangan syariah masih sangat rendah (OJK, 2017), yaitu sebesar 11,06\%. Adapun tingkat inklusi terendah terdapat di provinsi/wilayah Kantor Regional (KR) OJK 6, KR 8, dan KR 9 dengan rata-rata tingkat inklusi masingmasing sebesar $8,55 \%, 6,18 \%$, dan 6,40\%. Keterbatasan akses masyarakat terhadap produk keuangan syariah dapat menjadi salah satu penyebab masih rendahnya indeks inklusi tersebut. Berikut data sebaran jaringan kantor perbankan syariah per Desember 2016: 
Optimalisasi Laku Pandai Berbasis Masjid ...

Tabel 1

Penyebaran Kantor Cabang Bank Syariah

\begin{tabular}{|c|c|c|c|c|c|}
\hline \multirow{2}{*}{$\begin{array}{l}\text { KR } \\
\text { OJK }\end{array}$} & \multirow[t]{2}{*}{ Provinsi } & \multirow{2}{*}{$\begin{array}{l}\text { Jumlah } \\
\text { Kantor }\end{array}$} & \multicolumn{3}{|c|}{ Jaringan Kantor } \\
\hline & & & BUS & UUS & BPRS \\
\hline 1. & Banten \& DKI & 423 & 365 & 43 & 15 \\
\hline 2. & Jawa Barat & 404 & 314 & 40 & 50 \\
\hline 3. & DI Yogyakarta \& Jateng & 296 & 196 & 49 & 51 \\
\hline 4. & Jawa Timur & 289 & 195 & 43 & 51 \\
\hline 5. & Kepri, NAD, Sumbar, Sumut & 452 & 354 & 59 & 39 \\
\hline 6. & $\begin{array}{l}\text { Sulbar, Sulsel, Sulteng, Sul Tenggara, Sulut, } \\
\text { Gorontalo, Papua, Maluku }\end{array}$ & 153 & 126 & 12 & 15 \\
\hline 7. & $\begin{array}{l}\text { Bangka Belitung, Bengkulu, Lampung, } \\
\text { Sumsel }\end{array}$ & 196 & 148 & 17 & 31 \\
\hline 8. & Bali, NTB, NTT & 73 & 51 & 17 & 5 \\
\hline 9. & Kalimantan & 175 & 119 & 52 & 4 \\
\hline & & 2.461 & 1.868 & 332 & 261 \\
\hline
\end{tabular}

Sumber: Otoritas Jasa Keuangan. 2017. Roadmap Perkembangan Keuangan Syariah Indoneisa 2017 - 2019. Jakarta: Otoritas Jasa Keuangan.

Sedangkan untuk data indeks Literasi Keuangan Syariah Dan Indeks Inklusi Keuangan dapat dilihat sebegai berikut :

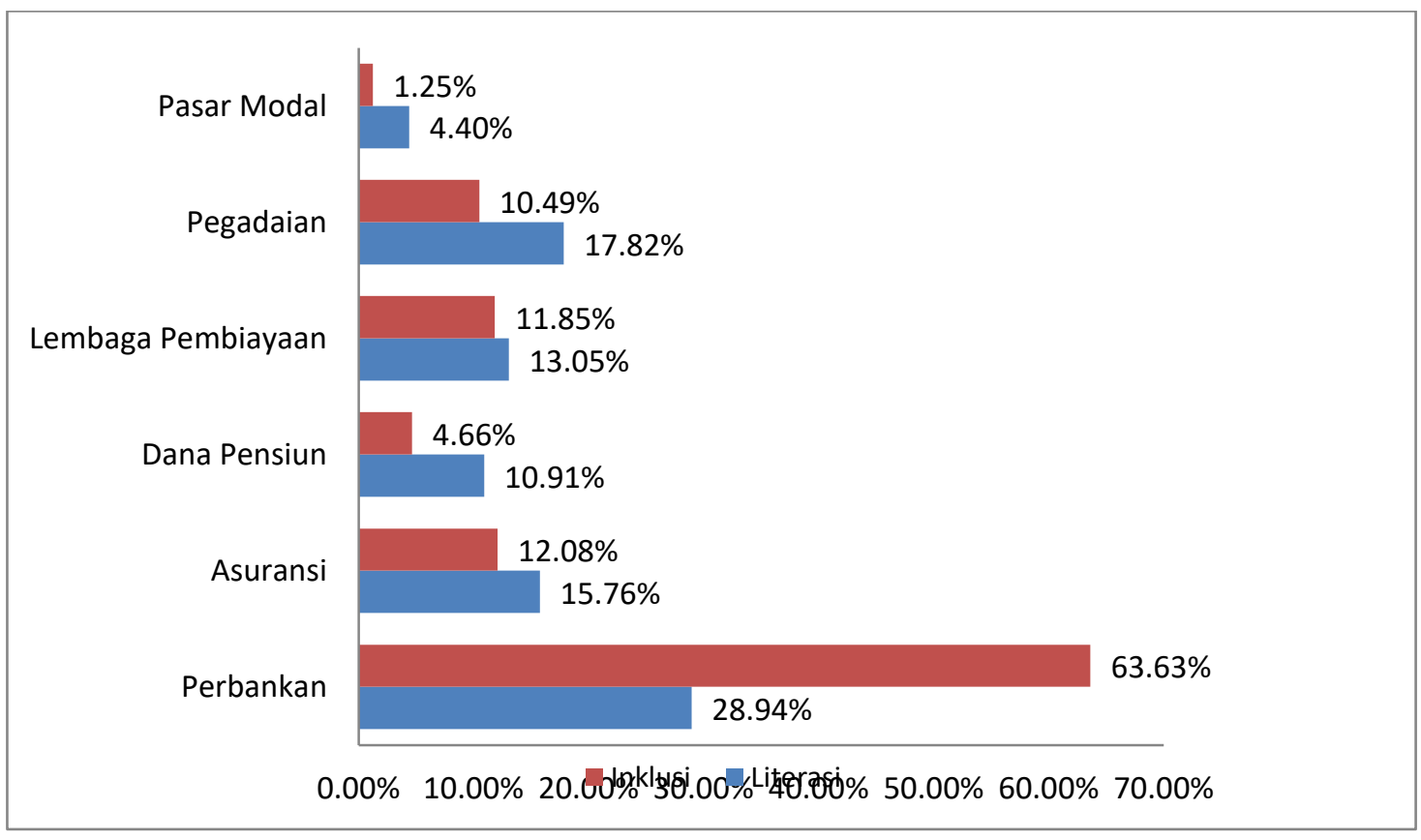


Putri \& Firmansyah |Jurnal Ekonomi dan Bisnis Islam, Vol. 3, No. 2, Juli-Des 2017

Sumber: Kompas, OJK: Indeks Literasi dan Inklusi Keuangan Indonesia Meningkat, diolah

Gambar 3 :Indeks Literasi Dan Indeks Inklusi Keuangan Syariah

Sebagai sistem keuangan yang berbasis kepada Islam, ekonomi syariah sudah seharusnya mendekatkan diri kepada pusat spiritual keislaman dalam hal ini Masjid. Sarana yang pertama kali dibangun Rasulullah SAW ketika berhijrah ke Madinah adalah Masjid. Masjid telah terbukti menjadi pusat peradaban di Madinah yang berkontribusi besar terhadap pembangunan karakter Masyarakat. Berbagai permasalahan dari mulai politik, militer, sosial hingga ekonomi ditemukan penyelesaian permasalahannya dengan berbasis Masjid. Peran dan fungsi Masjid yang berjalan dengan baik menjadikan masyarakat sangat mencintai Masjid dan setiap sendi kehidupannya selalu terikat dengan Masjid.

Menurut ketua Dewan Masjid Indonesia (DMI) Jumlah masjid di Indonesia sebanyak 800.000 (Tribun, 2017) dari jumlah tersebut baru sekitar 50\% yang terdata oleh kementrian agama sebagai berikut

Tabel 2

Jumlah Masjid dan Mushalla di Indonesia

\begin{tabular}{lll}
\hline No & Keterangan & Jumlah \\
& & \\
\hline 1. & Masjid Raya & 30 \\
2. & Masjid Agung & 364 \\
3. & Masjid Besar & 3,980 \\
4. & Masjid Jami & 180,627 \\
5. & Masjid Bersejarah & 726 \\
6. & Masjid di Tempat Publik & 33,129 \\
7. & Mushalla di Tempat Publik & 47,995 \\
8. & Mushalla di Perkantoran & 2,369 \\
9. & Mushalla Pendidikan & 5,979 \\
10. & Mushalla Perumahan & 153,693 \\
\hline Total & & $\mathbf{4 2 8 , 8 9 2}$ \\
\hline
\end{tabular}

Sumber: Kementrian Agama diambil dari website http://simas.kemenag.go.id/\#tabs1-js .

Masjid dan ekonomi mempunyai keterikatan yang sangat erat. Islam memandang kemiskinan akan lebih mendekatkan kepada kekufuran. Maka, selain memiliki fungsi spiritual Masjid wajib memberikan kotribusi untuk kesejahteraan perekonomian pada masyarakat. Masyarakat dengan tingkat kesejahteraan yang cukup akan memiliki kekhususan beribadah yang lebih stabil. 
Optimalisasi Laku Pandai Berbasis Masjid ...

Dengan fungsi ekonomi yang berjalan Masjid akan mampu melakukan pendanaan secara mandiri guna peningkatan sarana dan pelayanan untuk jamaah.

Salah satu strategi yang efektive untuk menjawab tantangan pengembangan perbankan syariah adalah dengan Laku Pandai. Laku Pandai adalah singkatan dari Layanan Keuangan Tanpa Kantor dalam Rangka Keuangan Inklusif. Dengan program Laku Pandai masyarakat tidak perlu datang ke kantor Bank syariah untuk mendapatkan layanan keuangan syariah. Agen Laku Pandai yang tersebar akan menyediakan layanan keuangan syariah dengan efektive dan efisien. Pendekatan sosial para agen dengan cara kekeluargaan dan mengedepankan kearifan lokal akan menarik minat masyarakat dan meningkatkan loyalitas perbankan syariah. Berlatar belakang tersebut penulis mencoba memaparkan solusi untuk tercapainya sinergi perbankan syariah dengan Masjid guna literasi dan inklusi keuangan syariah berkelanjutan.

\section{LANDASAN TEORI}

\section{Laku Pandai}

Layanan Keuangan Tanpa Kantor Dalam Rangka Keuangan Inklusif adalah kegiatan menyediakan layanan perbankan dan/atau layanan keuangan lainnya yang dilakukan tidak melalui jaringan kantor, namun melalui kerjasama dengan pihak lain dan perlu didukung dengan penggunaan sarana teknologi informasi (OJK, 2014).

Latar belakang diadakannya Laku Pandai adalah (1). Masih banyak anggota masyarakat yang belum mengenal, menggunakan, dan/atau mendapatkan layanan perbankan dan layanan keuangan lainnya, antara lain karena bertempat tinggal di lokasi yang jauh dari kantor bank dan/atau adanya biaya atau persyaratan yang memberatkan. (2). Otoritas Jasa Keuangan (OJK), industri perbankan, dan industri jasa keuangan lainnya berkomitmen untuk mendukung terwujudnya keuangan inklusif. (3). Pemerintah Indonesia mencanangkan program Strategi Nasional Keuangan Inklusif (SNKI) pada bulan Juni 2012, yang salah satu programnya adalah branchless banking. (4). Branchless banking yang ada sekarang perlu dikembangkan agar memungkinkan layanan perbankan dan layanan keuangan lainnya menjangkau segenap lapisan masyarakat di seluruh Indonesia (OJK, 2015).

Tujuan diadakannya program Laku Pandai adalah (1). Menyediakan produk-produk keuangan yang sederhana, mudah dipahami dan sesuai dengan kebutuhan masyarakat yang belum dapat menjangkau layanan keuangan saat ini. (2). Dengan semakin banyaknya anggota berbagai kelompok masyarakat di berbagai wilayah di Indonesia menggunakan layanan keuangan / perbankan, diharapkan kegiatan ekonomi masyarakat dapat semakin lancar sehingga mendorong pertumbuhan ekonomi dan pemerataan pembangunan antar wilayah di Indonesia terutama antara desa - kota (OJK, 2015). 
Produk yang disediakan lembaga keuangan yang menyelenggarakan program Laku Pandai adalah (1). Tabungan. (2). Kredit atau pembiayaan untuk nasabah mikro. (3). Asuransi mikro; dan/atau (4). Produk keuangan lainnya berdasarkan persetujuan Otoritas Jasa Keuangan (OJK, 2014).

\section{Fitur Laku Pandai}

Tabungan Laku Pandai memiliki karakteristik basic saving account sebagai berikut : (1). Hanya dapat dimiliki oleh perorangan Warga Negara Indonesia dalam mata uang Rupiah. (2). Tanpa batas minimum setoran. (3). Tanpa batas minimum saldo rekening. (4). Batas maksimum saldo rekening setiap saat ditetapkan paling banyak Rp20.000.000,00 (dua puluh juta rupiah) batas maksimum transaksi debet rekening berupa penarikan tunai pemindahbukuan dan/atau transfer keluar dalam 1 (satu) bulan secara kumulatif pada setiap rekening paling banyak Rp5.000.000,00 (lima juta rupiah) dalam 1 bulan namun tidak boleh lebih besar dari Rp. 60.000.000,00 dalam 1 tahun secara kumulatif dalam hal nasabah juga merupakan debitur bank. (5). Dibebaskan dari pembebanan biaya untuk administrasi bulanan, pembukaan rekening, transaksi penyetoran tunai, transaksi transfer masuk, transaksi pemindahbukuan dan penutupan rekening. (6). Biaya untuk tarik tunai, transfer keluar, pembayaran melalui rekening tabungan dan biaya lainnya ditetapkan oleh Bank dan harus lebih sedikit dari biaya transaksi serupa untuk rekening tabungan reguler. (7). Mendapatkan bunga atau bagi hasil melalui saldo rekening Rp. 1 (8). Tidak diperkenankan untuk rekening bersama dengan status dan dan atau (OJK, 2014).

Pembiayaan mikro diperuntukan bagi nasabah yang sudah memiliki tabungan BSA minimal 6 bulan yang dipergunakan untuk kegiatan usaha yang bersifat produktif atau kegiatan lainnya dalam rangka mendukung keuangan inklusif. Jangka waktu pembiayaan paling lama 1 tahun atau sesuai siklus usaha dengan maksimal plafond sebesar Rp. 20.000.000.000.

\section{Persyaratan Agen Laku Pandai}

Agen Laku Pandai bisa berasal dari perorangan atau badan hukum. Untuk agen perorangan persyaratannya adalah : (1). Bertempat tinggal di lokasi tempat penyelenggaraan Laku Pandai. (2). Memiliki kemampuan, reputasi, kredibilitas dan integritas yang baik. (3). Memiliki sumber penghasilan utama yang berasal dari kegiatan usaha dan atau kegiatan tetap lainnya paling singkat 2 tahun. (3). Belum menjadi Agen Laku Pandai dari bank lain. (4). Lulus proses uji tuntas (due diligence) oleh Bank penyelenggara Laku Pandai.

Sedangkan persyaratan menjadi agen Laku Pandai bagi badan hukum adalah sebagai berikut : (1). Berbadan hukum Indonesia yang diawasi oleh otoritas pengatur dan diperkenankan melakukan kegiatan dibidang keuangan. (2). Memiliki reputasi, kredibilitas, dan kinerja yang baik. (3). Memiliki usaha 
Optimalisasi Laku Pandai Berbasis Masjid ...

yang menetap di satu lokasi dan masih berlangsung paling singkat 2 tahun. (4). Mampu melakukan manajemen likuiditas sesuai yang dipersyaratkan oleh Bank penyelenggara. (5). Mampu menyediakan sumber daya manusia yang mempunyai kemampuan teknis untuk mendukung penyelenggaraan Laku Pandai. (6). Memiliki teknologi informasi yang memadai untuk mendukung penyelenggaraan Laku Pandai. (7). Lulus uji tuntas oleh Bank penyelenggara Laku Pandai.

\section{Kemudahan Laku Pandai bagi transaksi keuangan syariah}

Terdapat beberapa kemudahan Laku Pandai bagi transaksi keuangan syariah. (1). Bank penyelenggara tidak perlu melakukan investasi yang besar guna pembukaan kantor. (2). Nasabah akan dimanjakan dengan akses yang sangat mudah dan jarak yang dekat. (3). Menggunakan media yang sederhana yaitu dengan phonesel berbasis aplikasi andorid. Masyarakat di Indonesia sudah familiar dengan sistem android yang memudahkan penyelenggaraan Laku Pandai.

\section{Literasi dan Inklusi Keuangan Syariah}

Literasi Keuangan adalah pengetahuan, keterampilan, dan keyakinan, yang mempengaruhi sikap dan perilaku untuk meningkatkan kualitas pengambilan keputusan dan pengelolaan keuangan dalam rangka mencapai kesejahteraan. Sedangkan Inklusi Keuangan adalah ketersediaan akses pada berbagai lembaga, produk dan layanan jasa keuangan sesuai dengan kebutuhan dan kemampuan masyarakat dalam rangka meningkatkan kesejahteraan masyarakat (OJK, 2016). Terdapat beberapa dimensi yang dapat digunakan untuk mengukur literasi keuangan seseorang yaitu manajemen keuangan pribadi, bentuk simpanan di Bank, Asuransi dan investasi (Ariani, tt).

Tujuan Literasi Keuangan meliputi meningkatnya kualitas pengambilan keputusan keuangan individu; dan perubahan sikap dan perilaku individu dalam pengelolaan keuangan menjadi lebih baik sehingga mampu menentukan dan memanfaatkan lembaga, produk dan layanan jasa keuangan yang sesuai dengan kebutuhan dan kemampuan Konsumen dan/atau masyarakat dalam rangka mencapai kesejahteraan (OJK, 2016). Tujuan Inklusi Keuangan meliputi: meningkatnya akses masyarakat terhadap lembaga, produk dan layanan jasa keuangan PUJK. meningkatnya penyediaan produk dan/atau layanan jasa keuangan oleh PUJK yang sesuai dengan kebutuhan dan kemampuan masyarakat. Meningkatnya penggunaan produk dan/atau layanan jasa keuangan yang sesuai dengan kebutuhan dan kemampuan masyarakat. Meningkatnya kualitas penggunaan produk dan layanan jasa keuangan sesuai kebutuhan dan kemampuan masyarakat (OJK, 2016). 
Menurut survei yang dilakukan oleh Otoritas Jasa Keuangan (OJK) pada tahun 2016 diketahui bahwa literasi Indeks Literasi Keuangan di Indonesia dalah sebesar $29.66 \%$ meningkat $7.82 \%$ dari tahun 2013 yaitu sebesar $21.84 \%$. Indeks Inklusi Keuangan syariah 2016 sebesar 67.82\% meningkat 8.08\% dari tahun 2013 yaitu sebesar $59.74 \%$. Sedangkan keuangan syariah di Indonesia adalah sebesar $8.11 \%$ dan inklusi keuangan syariah sebesar $11.06 \%$. Data ini memberikan tugas kepada kita untuk senantiasa berusaha meningkatkan literasi dan inklusi keuangan syariah kepada masyarakat (OJK, tt).

Literasi keuangan syariah merupakan suatu kombinasi kesadaran, pengetahuan, sikap dan tingkah laku yang dibutuhkan untuk membuat keputusan-keputusan keuangan guna mencapai kemakmuran individu. Maka pengetahuan dan kesadaran tentang keuangan syariah penting karena tanpa hal tersebut mustahil seseorang akan melakukan kegiatan dengan perbankan syariah. Bahkan orang yang sudah memahami atau mempunyai kesadaran tentang bank syariah belum tentu melakukan transaksi melalui perbankan syariah (Isnuhardi, 2013). Inklusi finansial di Indoneisa terjadi disebabkan oleh dua kemungkinan. Kemungkinan pertama tidak punya akses karena tidak mampu atau tidak mau. Kemungkinan kedua tidak dapat. Bagi kelompok yang tidak mau bisa disebabkan karena merasa tidak perlu, alasan agama dan budaya. Sedangkan kelompok yang tidak dapat disebabkan karena tidak cukup pendapatan, risiko yang terlalu tinggi atau persyaratan yang tidak memenuhi (Khatimah, 2016).

Habib Ahmed dan Ak Md Hasnol Alwee Pg Md Salleh (Ahmed \& Salleh, 2016) menyebutkan bahwa inklusi keuangan dianggap sebagai alat kunci untuk pengentasan kemiskinan. Inklusi keuangan yang pada umumnya difokuskan kepada kalangan menengah keatas sebetulnya bisa diterapkan kepada masyarakat berpenghasilan rendah. Persyaratannya tersedianya berbagai instrumen dan produk yang sesuai dengan syariah untuk pengelolaan uang, emergency planing, investasi untuk tujuan tertenu dan transferencee planning.

Abul Hasan (Hasan, 2015) dalam penelitiannya menyatakan bahwa pembiayaan mikro syariah sebetulnya bisa menyasar kepada kelompok yang selama ini tidak terakses oleh lembaga keuangan konvensional. Adanya akses terhadap pembiayaan mikro syariah bisa menghindarkan kemiskinan bagi para keluarga yang miskin. Pelaksanaan strategi ini membutuhkan dalam jangka panjang bukan untuk jangka pendek. Maka keberlangsungan program perlu dijaga untuk keberhasilan yang paripurna.

Sebuah sistem keuangan yang inklusif harus memiliki pengguna sebanyak mungkin. Maka sistem keuangan inklusif harus menjangkau secara luas para pengguna. Proporsi dari populasi yang memiliki rekening Bank merupakan sebuah ukuran untuk penetrasi perbankan (Nengsih, 2015). 
Optimalisasi Laku Pandai Berbasis Masjid ...

Menurut Problem Inklusi keuangan syariah menjadikan distribusi dan jangkauan hal yang menantang dan berbiaya mahal di negara besar seperti Indonesia. Bank-bank syariah dengan kapasitas mereka yang terbatas dalam hal modal, sistem, produk dan sumber daya manusia cenderung untuk beroperasi di kota-kota besar dan kota-kota tempat terdapatnya bisnis yang lebih baik bagi mereka. Situasi ini merupakan rintangan dalam pertumbuhan bank syariah dan juga dalam kebijakan pemerintah di bidang keuangan inklusif. Jangkauan ke daerah-daerah yang saat ini terlayani oleh bank-bank syariah dapat secara signifikan ditingkatkan dengan menggunakan model distribusi alternatif. Dua model yang menjadi semakin populer di beberapa belahan dunia adalah: (1). Movable branch - kendaraan khusus yang dilengkapi dengan peralatan dan menawarkan layanan yang hampir lengkap termasuk ATM untuk penanganan uang tunai. (2). Branchless banking - model baru yang melibatkan bisnis lokal dan terkadang jaringan operator telekomunikasi nasional, yang menggunakan kombinasi agen lokal dan teknologi telepon seluler untuk menawarkan layanan dasar dengan persyaratan yang ringan dalam aspek pengenalan nasabah atau KYC (Know Your Customer). Layanan jenis baru ini akan membantu memperluas jangkauan dan meningkatkan keuangan inklusif dengan mengurangi hambatan termasuk biaya, waktu perjalanan, dan persyaratan dokumentasi (BAPENAS, 2016).

\section{METODE PENELITIAN}

Penelitian ini merupakan penelitian kualitatif (Budiasih, 2014) dengan menggunakan metode grounded theory. Riset ini dimulai dari data untuk menemukan teori tertentu. Peneliti mengamati, mengumpulkan, dan mengorganisasi data serta membentuk teori dari data pada waktu yang bersamaan. Riset kualitatif dengan metode ini dimulai dengan fokus pada wilayah studi dan mengumpulkan data dari berbagai sumber, termasuk jika diperlukan wawancara dan observasi. Selanjutnya data dianalisis menggunakan pengkodean dan prosedur sampling teoritis.

\section{HASIL DAN PEMBAHASAN}

\section{Produk yang dipasarkan}

Produk pertama yang dipasarkan adalah tabungan yang diperuntukan untuk sarana ibadah. Setiap Muslim pasti menginginkan untuk melaksanakan seluruh peribadatan yang telah disyariatkan. Dalam syariah Islam ada beberapa peribadatan yang memerlukan biaya tertentu diantaranya Qurban, Umroh dan Haji. Mayoritas masyarakat tidak bisa memenuhi biaya untuk melaksanakan peribadatan tersebut dalam waktu yang singkat karena faktor cashflow yang tidak sesuai. Maka perlu diadakannya edukasi untuk melakukan tabungan yang 
Putri \& Firmansyah |Jurnal Ekonomi dan Bisnis Islam, Vol. 3, No. 2, Juli-Des 2017

dananya khusus akan diperuntukan mendukung pelaksanaan peribadatan tersebut.

Bagi masyarakat di pedesaan kondisi untuk menabung mempunyai problem inklusi keuangan syariah. Ketiadaan akses menyebabkan mereka tidak bisa mendapatkan layanan tersebut. Sehingga jika ingin menabung harus menempuh jarak yang cukup jauh. Bagi masyarakat perkotaan problem berada pada kelonggaran waktu untuk melakukan setoran. Kesibukan jam kantor tidak membuat fleksibilitas untuk hanya sekedar melakukan setoran.

Maka dengan adanya agen Laku Pandai berbasis Masjid masyarakat pedesaan bisa melakukan setoran dengan mudah karena cukup datang ke agen Laku Pandai maka transaksi bisa dilakukan. Setoran juga bisa dilakukan ketika bersamaan dengan event pengajian di Masjid dan disetor langsung kepada agen Laku Pandai di Masjid. Bagi masyarakat perkotaan setoran bisa dilakukan dengan fleksible dan tidak dibatasi dengan jam kantor. Setelah pulang bekerja mereka bisa mendatangi agen Laku Pandai untuk melakukan setoran tersebut.

Dana Masjid yang berhasil terhimpun sangat besar. Menurut adnan potensi dana Masjid adalah sebesar $\$ 30.000 .000$., jika asumsi kurs sebesar Rp. 13.332 per dolar maka potensi dana Masjid yang ada sebesar Rp. 399.960.000.000., dana sebesar itu bisa dilakukan pengelolaan dengan cara dimasukan ke rekening pebankan syariah melalui agen Laku Pandai. Dikarenakan limit tabungan Laku Pandai adalah sbesar Rp. 20.000.000 maka skema yang dilakukan adalah transfer atau over booking ke rekening atas nama Masjid di perbankan syariah (Adnan, tt). Dengan dimasukannya dana tersebut ke rekening di Bank syariah maka akan menjadikan pengelolaan dana Masjid menjadi lebih baik dan aman. Selain itu dana tersebut akan disalurkan oleh perbankan syariah ke sekor rill sehingga akan berpengaruh positif tehadap perekonomian nasional.

Produk kedua dalah jasa pembayaran. Pulsa, token listrik dan internet sudah menjadi kebutuhan pokok masyarakat di perkotaan dan pedesaan. Menurut hasil survei APJII tahun 2016 dari jumlah penduduk Indonesia pengguna internet adalah sebanyak 132.7 juta. 63.1 juta orang mengakses internet dari handphone dan 67.2 juta mengakses dari handphone dan komputer. Sebanyak 93.4 juta orang menganggap aman transaksi online perbankan (APJII, 2016).

Dengan potensi tersebut maka agen Laku Pandai membuka layanan pembelian token, pulsa dan internet untuk masyarakat. Dari pembelian tersebut agen bisa menarik fee dan disumbangkan untuk kemakmuran Masjid. Sehingga transaksi pembelian pulsa dan sejenisnya melalui agen Laku Pandai akan diberikan tagline "beli pulsa dapat pahala". Dengan transaksi ini maka Masjid akan mendapatkan sumber pendanaan untuk membiayai kegiatan operasionalnya. 
Produk ketiga adalah pembiayaan Mikro. Adanya agen Laku Pandai memungkinkan adanya pembiayaan mikro bagi masyarakat sekitar. Sehingga masyarakat pedesaan yang kesulitan untuk mendapatkannya bisa memperoleh layanan guna meningkatkan taraf hidup dan kesejahteraannya. Pembiayaan mikro melalui agen laku pandai berbasis Masjid akan sangat efektif karena analisa 5 C (Caracter, capital, colateral, capacity and condition of economic) bisa dilakukan dengan rekomendasi dari agen dan pengurus Masjid yang mengetahui kehidupan serta karakter calon nasabah. Tentu jika ada permasalahan pembayaran nasabah akan merasa sungkan karena akan selalu bertemu dengan pengurus Masjid dan agen Laku Pandai dalam bermasyarakat sehingga bisa meminimalisir potensi gagal bayar.

\section{Penyelenggaraan Literasi}

Masjid merupakan central kegiatan spiritual umat Islam. Dengan adanya tokoh keagamaan di Masjid (ulama) maka akan menggerakan masyarakat dengan mudah. Jika tokoh masyarakat menyerukan untuk melakukan kegiatan keuangan melalui keuangan syariah maka sebagian masyarakat akan melakukannya. Dengan pengaruh tokoh masyarakat dan ulama dalam pengembangan literasi keuangan syariah akan menjadi lebih ringan. Kegiatan literasi dilakukan dengan menyusun tema keuangan syariah yang akan dibawakan oleh penceramah dalam berbagai kegiatan ceramah baik pengajian ataupun khotbah jumat. Dengan adanya program dan kurikulum yang baik maka indeks literasi keuangan syariah akan membaik.

Pengkaderan merupakan suatu hal yang esensial guna keberlangsungan program dalam jangka panjang. Maka perlu dilakukan pengkaderan dalam program ini kepada beberapa pihak sehingga program ini bisa berjalan dalam jangka panjang. Kegiatan training for trainers dilakukan kepada para ulama dan remaja Masjid.

Ulama merupakan tokoh keagamaan yang sangat dihormati dan diikuti oleh masyarakat. Namun tidak semua ulama sudah mengenal keuangan syariah maka tentu perlu adanya pendidikan yang terstruktur untuk mensosialisasikan keuangan syariah kepada kalangan ulama.

Remaja Masjid merupakan generasi muda yang kedepan akan menjadi tokoh masyarakat. Kegiatan di lingkungan Masjid diselenggarakan oleh remaja Masjid. Usia yang masih muda serta semangat yang tinggi menjadikan daya juang remaja Masjid sangat loyal. Dengan latar belakang tersebut maka perlu diadakan training for trainers untuk kalangan remaja Masjid. Diharapkan event organizer literasi keuangan syariah di Masjid dimotori oleh remaja masjid dan diisi oleh ulama setempat yang diakui ketokohannya. Dalam beberapa tahun remaja Masjid inilah yang akan menggantikan ulama untuk melanjutkan program ini. 


\section{Pihak pihak terkait}

Untuk melaksanakan program ini ada beberapa pihak yang terkait. OJK sebagai regulator mengawal program ini. Bank Umum syariah sebagai pihak yang menyediakan layanan Laku Pandai. Akademisi sebagai pemateri untuk pelatihan bersama ulama. Pemerintah melakukan dukungan program ini. DMI dan Kementrian Agama sebagai pihak yang mengorganisir Masjid melakukan koordinasi dengan Masjid.

\section{Efek dari sinergi Laku Pandai dengan Masjid}

Efek yang akan timbul dari aplikasi sinergi ini sangat beragam. Inklusi keuangan akan membaik karena ketersediaan layanan keuangan syariah terutama bagi masyarakat pedesaan. Literasi keuangan berjalan optimal dengan sosialisasi berbasis Masjid dimana program ini dipimpin oleh ulama dan tokoh masyarakat setempat. Cash and saving accounts (CASA) perbankan syariah akan meningkat dengan adanya penambahan sumber dana pihak ketiga melalui tabungan berbasis Laku Pandai. Market share perbankan syariah akan meningkat karena mengoptimalkan penetrasi pemasaran ke daerah pedesaan yang belum tersentuh oleh perbankan pada umumnya. Masjid akan menjadi makmur karena kegiatan bebasis ekonomi berjalan dengan baik. Masyarakat akan lebih bersemangat untuk terlibat dalam kegiatan peribadatan spiritual dan sosial karena merasakan kesejahteraan ekonomi yang berasal dari Masjid. Masyarakat bisa mendapatkan pembiayaan mikro dengan mitigasi risiko yang baik. Efek positif yang terjadi dengan pembiayaan mikro akan meningkatkan kesejahteraan dan mengentaskan kemiskinan masyarakat terutama di daerah pedesaan.

\section{SIMPULAN}

Problem kurangnya inklusi dan literasi keuangan syariah di Indonesia bisa diselesaikan salah satunya dengan program Laku Pandai berbasis Masjid. Perbankan Syariah melakukan reikrutmen Agen Laku Pandai dengan pusat kegiatan dan literasi berbasis Masjid. Dengan kegiatan tersebut masyarakat akan mendapatkan akses untuk mendapatkan layanan keuangan syariah sekaligus bisa memperdalam pengetahuan keuangan syariah. Para pihak terkait melakukan kegiatan literasi dengan mengadakan berbagai kajian bertemakan keuangan syariah dengan tahapan dan kurikulum yang bertahap.

Saran yang diajukan dari penelitian ini Otoritas Jasa Keuangan (OJK) bersama dengan perbankan syariah, Dewan Masjid Indonesia (DMI), Pemerintah dan Tokoh Agama melakukan pemetaan potensi pemasaran guna pelaksanaan Laku Pandai berbasis masjid terutama untuk daerah pedesaan. Merancang program dan kurikulum yang terarah dan berkelanjutan guna pelaksanaan program. Melaksanakan sosialisasi kepada Masjid-Masjid melalui Dewan Masjid Indonesia (DMI) dan Kementrian Agama tentang manfaat dan peluang program 
Laku Pandai Berbasis Masjid yang akan memberikan pengarus positif terhadap kesejahteraan masyarakat. Kementrian Agama bersama Otoritas Jasa Keuangan membuat format pencatatan keuangan masjid sekaligus merancang regulasi guna penempatan dana Masjid di perbankan syariah guna pengelolaan keuangan yang lebih baik dan terarah. Merangkul generasi muda melalui Remaja Masjid guna kaderisasi keberlangsungan program dalam jangka panjang.

\section{DAFTAR PUSTAKA}

Adnan, Muhammad Akhyar, The Financial Management Practices of the Mosques in Special Region of Yogyakarta Province Indonesia, Tazkia Islamic Finance and Bussines Review, 8(2), 139.

Ahmed, Habib dan Salleh, Ak Md Hasnool Alwee Pg Md, 2016. Inclusive islamic Financial Planing : a Conceptual Framwork. International Journal of Islamic and Middle Eastern Finance and Management, 9 (2), 185.

Alanshori, M. Zainudin, 2016. Perkembangan, Tantangan dan Peluang Bank Syariah, JES Volume 1 Nomor 1 September 2016.

Ariani, Nur Aziza. Pengaruh Faktor Demografi Terhadap Financial Literacy Mahasiswa Fakultas Ekonomi Universitas Negeri Surabaya Angkatan 2012 t.tp: tp.

Asosiasi Penyelenggara Jasa Internet Indonesia. (2017). Survei Penetrasi \& Perilaku Pengguna Internet Indonesia 2016. Jakarta: Asosiasi Penyelenggara Jasa Internet Indonesia.

Badan Perencanaan Pembangunan Nasional (BAPPENAS). (2016) Masterplan Arsitektur Keuangan Syariah Indonesia, Jakarta : BAPPENAS.

Budiasih, I Gusti Ayu Nyoman. 2014. "Metode Grounded Theory dalam riset kualitatif." Jurnal Ilmiah akuntasi dan Bisnis 9(1), 27-19.

Hasan, Abul, .2015. Financial Inclusion of the Poor : From Microcredit to Islamic Microfinancial Services. Humanomics 31 (3), 368-369.

Isnuhardi, 2013. Kajian Tingkat Literasi Masyarakat Terhadap Perbankan Syariah. (Studi Kasus : Masyarakat Kota Palembang). Palembang : Progran Studi Magister Manajemen Fakultas Ekonomi Universitas Sriwijaya.

Kementrian Agama Republik Indonesia, http://simas.kemenag.go.id/\#tabs1-js

Khatimah, Husnul, 2016. Analisis Evektifitas Inklusi Keuangan di BMT Syariah Riyal. Jurnal Ilmiah Ekonomi Manajemen Kewirausahaan "Optimal“ 10 (2), 134. 
Putri \& Firmansyah |Jurnal Ekonomi dan Bisnis Islam, Vol. 3, No. 2, Juli-Des 2017

Nengsih. Novia, 2015. Peran Perbankan Syariah dalam Mengimplementasikan Keuangan Inklusif di Indonesia. Jurnal Ekonomi 14(2).

Otoritas Jasa Keuangan. 2015. Seputar Informasi Mengenai Layanan Keuangan Tanpa Kantor Dalam Rangka Keuangan Inklusif. Jakarta : Otoritas Jasa Keuangan.

Otoritas Jasa Keuangan. 2017. Roadmap Perkembangan Keuangan Syariah Indoneisa 2017 - 2019. Jakarta: Otoritas Jasa Keuangan.

Otoritas Jasa Keuangan. 2017. Survei Nasional Literasi dan Inklusi Keuangan. Jakarta: Otoritas Jasa Keuangan.

Peraturan Otoritas Jasa Keuangan nomor 19/POJK.03/2014 tentang Layanan Keuangan Tanpa Kantor Dalam Rangka Keuangan Inklusif.

Peraturan Otoritas Jasa Keuangan nomor 76 /POJK.07/2016 Tentang Peningkatan Literasi Dan Inklusi Keuangan Di Sektor Jasa Keuangan Bagi Konsumen Dan/Atau Masyarakat.

Thomson Reuters, tt. Islamic Finance Development Report 2015,

Tribun Travel (2017, Maret

http://travel.tribunnews.com/2017/03/04/dikira-8000-ternyata-jumlahsebenarnya-Masjid-di-indonesia-bikin-raja-arab-terkejut

Kompas (2017, January 24), OJK: Indeks Literasi dan Inkluasi Keuangan Indonesia Meningkat.

http://ekonomi.kompas.com/read/2017/01/24/180000626/ojk.indeks.li terasi.dan.inklusi.keuangan.indonesia.meningkat.

Undang Undang nomor 21 tahun 2008 tentang Perbankan Syariah. 